\title{
Jakost vody ve vodárenské nádrži Švihov na Želivce a jejím povodí se zaměřením na specifické organické látky
}

\author{
MAREK LIŠKA, KATEŘINA SOUKUPOVÁ, JAKUB DOBIÁŠ, ANTONIA METELKOVÁ, \\ JAN GOLDBACH, TOMÁŠ KVÍTEK
}

Klíčová slova: VN Švihov - fosfor - pesticidy - léčiva - bodové - plošné zdroje znečištění

\section{SOUHRN}

Povodí největší české vodárenské nádrže Švihov na Želivce je výrazně antropogenně ovlivněno, a to jak prímým pưsobením člověka, tak i intenzivní zemědělskou činností. Jakost povrchové vody je zde dlouhodobě ohrožována zejména eutrofizací, prítomností pesticidních látek a erozí. Vyšší koncentrace fosforu původem z bodových zdrojů je příčinou pokročilé eutrofizace toků. Způsob zemědělského obhospodařování podporuje rozsáhlou erozi zemědělské půdy a její sedimentaci v tocích a nádržích. Pesticidní látky pocházející zejména ze zemědělské produkce jsou nacházeny ve zvýšených koncentracích $v$ drenážních i povrchových vodách v povodí VN Švihov. S živinami v odpadních vodách se do toků dostávají i další cizorodé látky, jako jsou např. léčiva, hormonální prípravky, kosmetické prípravky, antikoroziva, bisfenol A a další. Pesticidní látky i léčiva se mění na jednotlivé metabolické produkty, které ve vodě v rưzných formách přetrvávají. Z hlediska dlouhodobého výhledu je přechod na pěstování technických plodin $v$ povodí vodárenské nádrže značným rizikem se závažnými důsledky pro kvalitu vody.

\section{ÚVOD}

Vodní nádrž Švihov na Želivce (dále jen VN Švihov) je největší českou vodárenskou nádrží, která poskytuje surovou vodu pro úpravu na vodu pitnou pro více než 1,2 mil. obyvatel České republiky. Plocha povodí je 1178 km², objem nádrže je 266 mil. $m^{3}$ s teoretickou dobou zdržení přibližně 430 dní. Nádrž je situována v zemědělsky intenzivně obhospodařované krajině, podíl zemědělsky užívaných ploch v povodích jednotlivých prítoků se pohybuje v rozmezí 50-80 \%. Na rozsáhlých plochách se zde pěstují plodiny s kombinovaným využitím (částečně jako zdroj substrátu pro bioplynové stanice), především se jedná o širokořádkové plodiny, zejména kukuřici, řepku a brambory. Ve velkém měřítku se zde používají prostředky na ochranu rostlin [1]. Oblast je značně antropogenně zatížená lidskými sídly a z části i průmyslovou výrobou.

Nedílnou součástí povodí VN Švihov jsou představné vodní nádrže: Němčice na Sedlickém potoce, Trnávka na vodním toku Trnava a vodní nádrže Sedlice a Vřesník na vodním toku Želivka. Tyto nádrže příznivě ovlivňují jakost povrchové vody, nebot z velké části zachycují splaveniny z povodí a zabraňují tak jejich usazování ve VN Švihov. Z hlediska retence živin se účinnost těchto tří představných nádrží pohybuje v rozpětí 20-50 \% zachyceného fosforu [2].
Jakost povrchové vody ve VN Švihov je ohrožována zejména následujícími faktory: eutrofizací, přítomností pesticidních látek, erozí a možnou nevyrovnaností hydrologického režimu [2-4].

\section{VÝSLEDKY A HODNOCENÍ}

\section{Bodové zdroje znečištění v povodí vodárenské nádrže Švihov}

Státní podnik Povodí Vltavy aktuálně eviduje $v$ povodí VN Švihov $\vee$ souladu s ustanovením § 21 a § 22 vodního zákona 91 bodových zdrojů znečištění, kterými jsou odpadní vody vypouštěné do vodních tokủ z ČOV, nebo prímo z kanalizací. Většinu zdrojů predstavují komunální odpadní vody z obcí a měst. Průmyslové zdroje jsou zastoupeny pouze minoritně, přičemž nejvýznamnějším zdrojem je papírna CEREPA Červená Řečice. Většina zdrojů OV patří mezi malé zdroje znečištění do 500 ekvivalentních obyvatel (dále jen EO). Velké zdroje nad 100 tis. EO nejsou v povodí vodárenské nádrže Švihov zastoupeny vůbec, mezi střední zdroje 2 - 100 tis. EO patří dva zdroje komunální - města Pelhřimov [4] a Pacov a jeden zdroj průmyslový - CEREPA Červená Řečice.

$\checkmark$ celém povodí VN Švihov na Želivce byly v průběhu let vybudovány čistírny odpadních vod ve všech obcích nad 500 obyvatel a některé z nich již byly postupně intenzifikovány. Ve II. ochranném pásmu tohoto vodního zdroje byly vybudovány ČOV často i v menších obcích. Nové čistírny (vybudované $\checkmark$ posledních letech) a některé starší intenzifikované disponují technologií pro zvýšenou biologickou eliminaci dusíku a fosforu s možností chemického srážení fosforu [5]. U největšího průmyslového zdroje organického znečištění v povodí (papírna CEREPA) bylo vybudováno v průběhu minulých let efektivní mechanické čištění s biologickým dočištovacím stupněm a recirkulací technologické vody. Toto opatření vedlo k celkovému snížení vypouštěného znečištění, avšak nijak zatím není řešeno odstraňování specifických organických látek, např. bisfenolu A, který se pravděpodobně uvolňuje do odpadních vod při zpracování recyklovaného papíru.

Likvidace odpadních vod v obcích menších než 500 EO naráží na nedostatek finančních prostředků pro výstavbu kanalizačních systémů a čistíren a navržená projektová řešení se proto často přizpůsobují ekonomické situaci obcí. Z úsporných důvodů byly navrhovány tzv. prírodě blízké způsoby čištění, např. biologické rybníky s předřazeným mechanickým stupněm s využitím stávající kanalizace [4]. 
Jejich účinnost je však relativně nízká a čisticí proces nelze prakticky ovlivnit. Využití stávajících obecních kanalizací je značná komplikace pro efektivní způsoby čištění odpadních vod z malých obcí. Většinou se jedná o starší stavby postavené v „akci Z“, které pro odvádění odpadních vod nejsou vhodné, a to jak z hlediska stavebního, tak i legislativního. Netěsné kanalizační systémy mají velký průnik balastních vod a tomu je v návrzích řešení čištění odpadních vod přizpůsobována hydraulická a celková kapacita ČOV. Takto navržené sestavy ČOV jsou finančně nákladné a většinou neodpovídají požadavkům na použití nejlepších dostupných technologií.

Malým obcím je ve většině prípadů vydáváno nové povolení k vypouštění odpadních vod z kanalizací bez čištění na dobu max. 4 let s podmínkou zajištění čištění odpadních vod, prípadně získání alespoň územního a stavebního povolení. Z hlediska eliminace specifických organických látek (léčiva, některé pesticidy (glyphosat), PPCPs a další) nemají ČOV v povodí VN Švihov instalovány žádné nadstandardní separační stupně (např. GAU). Znamená to, že tyto látky nejsou bud' odstraňovány vůbec, nebo s omezenou účinností na úrovni schopností standardního technologického vybavení [6].

Z hlediska vlivu eutrofizace Ize za nejrizikovější faktor v povodí VN Švihov považovat fosfor z bodových zdrojů zněčištění, tj. reaktivní formu fosforu, která je hlavní živinou pro růst fytoplanktonu ve vlastní VN Švihov $[2,3]$. Současný stav je třeba vnímat s opatrným optimismem, koncentrace fosforu v př́toku do nádrže se po rozsáhlých investicích do čistíren odpadních vod víceméně stabilizovala s mírným nárůstem v posledních dvou letech, který pravděpodobně souvisel s rekonstrukcí a sníženou čisticí schopností pelhřimovské ČOV (obr. 1) [4].

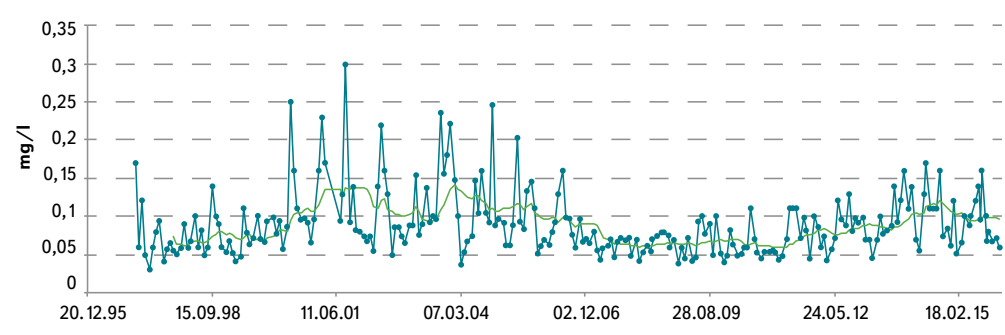

Obr. 1. Dlouhodobý vývoj koncentrace celkového fosforu 1997-2015 na př́toku do nádrže VN Švihov

Fig. 1. Long-term trend of phosphorus concentration in the main tributary of Švihov water reservoir

\section{Výskyt farmak v povrchových vodách VN Švihov původem z bodových zdrojů}

Z bodových zdrojů znečištění se do povrchových vod dostávají také např. humánní a veterinární léčiva a další specifické látky, např. již zmiňovaný bisfenol A, benzotriazoly a další látky. Na obr. 2-5 jsou zobrazeny koncentrace vybraných měřených léčiv ve vypouštěných odpadních vodách z ČOV Pelhřimov a koncentrace $v$ toku Bělá (pod místem vypouštění odpadních vod) a dále na př́toku do VN Švihov. Vodohospodářské laboratoře státního podniku Povodí Vltavy měři koncentrace léčiv jak v povrchové, tak i v odpadní vodě na odtocích u vybraných významných čistíren odpadních vod [1, 6]. Jsou sledovány zejména účinné látky následujících skupin léčiv: antihypertenziva (hydrochlorthiazid, metroprolol), antirevmatika a antiflogistika (diclofenac, ibuprofen), látky tlumící bolest (gabapentin, tramadol), antiepileptika a antidepresiva (karbamazepin) a rentgen diagnostické látky (iopamidol, iopromid) a některé další. Z přiložených grafů je velmi dobře patrné, že i přes několikanásobné ředění a metabolizaci farmaceutických prípravků jsou tyto látky měřitelné ve velké vzdálenosti od bodového zdroje. V odpadních vodách ČOV se tyto látky vyskytují až v "mikrogramových“ množstvích, po přepočtu na látkovou bilanci se jedná o jednotky až „desítky“ kilogramů ročně pro různé účinné látky vybraných přípravků. Pravděpodobně je však detekována pouze malá část používaných léčiv, nebot̉ zavádění laboratorních diagnostických metod na stanovení metabolických produktů účinných látek jednotlivých farmaceutických přípravků je zatím v počátku [7]. Můžeme tedy předpokládat, že reálné nálezy (ve vztahu k užívaným množstvím) by pravděpodobně byly vyšší. V současné době vodohospodářské laboratoře státního podniku Povodí Vltavy začaly stanovovat také dva metabolity ibuprofenu (2-hydroxyibuprofen a karboxyibuprofen) a nálezy těchto látek v odpadní i povrchové vodě jsou vyšší než u ibuprofenu (jakožto rodičovské látky).

\section{Výskyt dalších organických látek v povodí VN Švihov pocházejících z bodových zdrojů}

$\checkmark$ rámci této kapitoly je vhodné zmínit výskyt látky bisfenol $A \vee$ povodí řeky Trnavy. Bisfenol A je látka, která patři do skupiny tzv. chlorovaných fenolů a je používána jako změkčovací prísada do plastů, termopapírů a dalších výrobků. Její př́tomnost v lidském těle pravděpodobně ovlivňuje žlázy s vnitřní sekrecí, plodnost a některé další funkce lidského organismu. Na profilu Želivka-Pořičí byla opakovaně, ne však pravidelně, nalézána uvedená látka ve vodě v koncentracích 30-150 ng/l. Laboratoře státního podniku Povodí Vltavy tak zahájily monitoring za účelem vyhledání zdroje. Za zdroj kontaminace byla označena papírna CEREPA, a. s., která vypouští odpadní vody do vodního toku Trnava nad nádrží Trnávka. V povrchové vodě v profilu "Trnava pod JIP“, tj. pod zaústěním odpadních vod z papírny, byly během léta a podzimu r. 2015 naměřeny vysoké koncentrace této látky: 2500 ng/l (15. 7.), 4600 ng/l (27. 7.) a 2000 ng/l (19. 10.). Sledování bisfenolu A bylo rozšíreno o profily Trnava-VN Trnávka hráz a profil Trnava-Brtná (profil monitorující jakost vody, odtékající z VN Trnávka do Želivky). Na těchto profilech se koncentrace bisfenolu A pohybovaly v rozpětí hodnot 50-300 ng/l. V samotné VN Švihov jsme po celou dobu sledování bisfenolu A hodnotu nad mezí detekce (30 ng/l) nenaměřili. Je pravděpodobné, že dochází k rozpadu této látky a její metabolizaci na jiné produkty, které však laboratoř státního podniku Povodí Vltavy zatím není schopná stanovit. V průběhu sledovaného období byly odebrány také vzorky sedimentu v části nad ponořeným stupněm VN Trnávka. Měřitelné hodnoty však ve vzorcích sedimentu nalezeny nebyly. O nálezu bisfenolu A byla informována Česká inspekce životního prostředí (ČlŽP - inspektorát Havlíčkův Brod), která věc prošetřila a dále informovala $v$ této věci odbor životního prostředí a zemědělství Krajského úřadu Vysočina. Zdrojem této látky je patrně zpracovávaný recyklovaný papír, během jehož zpracování se ž̌ejmě bisfenol A v něm obsažený uvolňuje do odpadních vod (tabulka 1).

Hodnoty bisfenolu A naměřené v řece Trnavě pod zaústěním odpadních vod z ČOV CEREPA byly korelovány s hodnotami průtoku naměřenými na limnigrafu umístěném na stejném profilu. Nebyla však nalezena jednoznačná

Tabulka 1. Naměřené hodnoty koncentrace bisfenolu A a prümërných denních prưtoků na profilu Trnava pod JIP

Table 1. Measured values of concentration of bisphenol A and the average daily flow rates at Trnava profile under the paper mill factory

\begin{tabular}{llllllll}
\hline & 29.6 .2015 & 15.7 .2015 & 27.7 .2015 & 5.8 .2015 & 24.8 .2015 & 21.9 .2015 & 19.10 .2015 \\
\hline bisfenol A ng/l & 2200 & 2500 & 4600 & 910 & 2500 & 88 \\
\hline průtok m $\mathrm{s} / \mathrm{s}$ & 0,55 & 0,31 & 0,31 & 0,26 & 0,36 & 0,23 \\
\hline
\end{tabular}


závislost na průtoku, což je zřejmě důsledkem nerovnoměrné koncentrace bisfenolu A ve vypouštěných odpadních vodách z ČOV CEREPA. Z pohledu hodnocení suchého období v roce 2015 a zde popisovaného prípadu je zřejmé, že zejména u bodových zdrojů znečištění nebude vždy zcela jednoduché ríci, jaký podíl na zvýšené koncentraci dané látky v toku má snižený průtok a jak velký význam má zvýšená "dávka“ z bodového zdroje. Abychom toto mohli říci, bylo by vždy nutné znát látkovou bilanci emisí dané látky od znečištovatele [8].

Dalšími látkami, které se v povrchových vodách VN Švihov vyskytují, jsou např. tzv. mošusové látky (tj. syntetické vonné látky), které se do našich toků dostávají z kosmetiky, pracích prostředků atd. (obr. 6). Významnější koncentrace např. galaxolidu se vyskytují pod čistírnami odpadních vod. Na hlavním přitoku do VN Švihov jsou již hodnoty této látky pouze ve výši několika desítek nanogramů.

\section{Pesticidní látky pocházející z plošných zdrojů znečištění v povodí vodárenské nádrže Švihov}

Povodí VN Švihov je hustě osídlené a intenzivně zemědělsky využívané. Více než $55 \%$ plochy povodí VN Švihov tvoří orná půda, přičemž mezi nejvíce zorněné oblasti patr̂́ povodí Čechtického potoka (téměř $75 \%$ ), situované nejblíže vodárenskému odběru. Za posledních 10 let se značně změnil způsob obhospodařování pưdy.

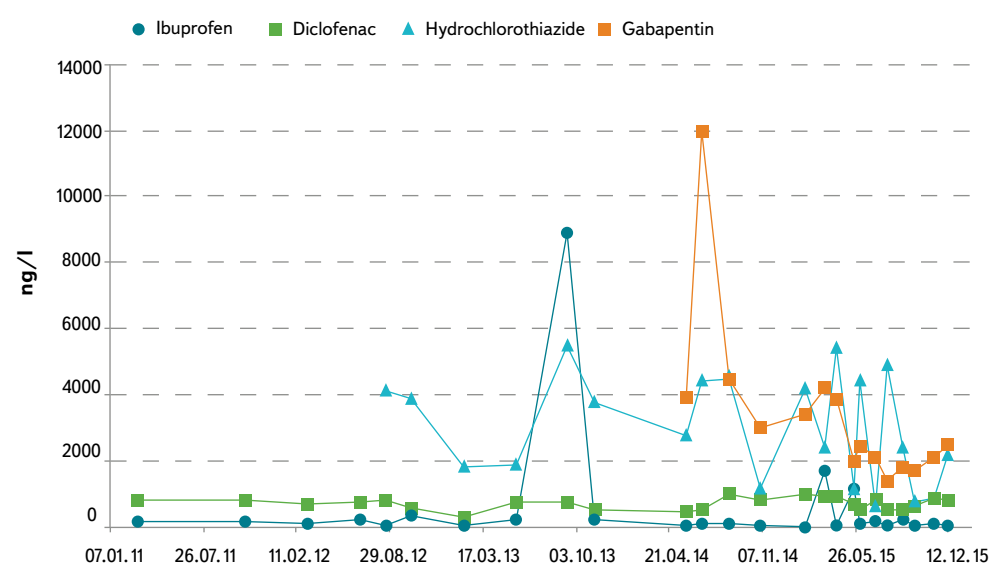

Obr. 2. Vývoj koncentrací vybraných léčiv ve vypouštěných odpadních vodách z ČOV Pelhřimov (technologická linka)

Fig. 2. Long-term trend of concentration of selected drugs in the Pelhřimov WWTP wastewater

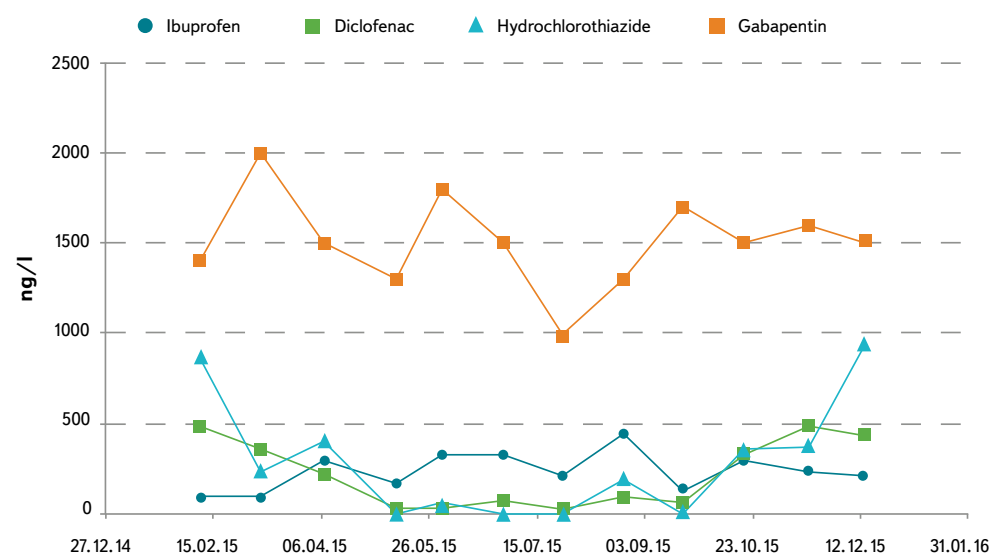

Obr. 3. Vývoj koncentrací vybraných léčiv ve vypouštěných odpadních vodách z II. biologického rybníka ČOV Pelhřimov

Fig. 3. Long-term trend of concentration of selected drugs in the second biological pond below the Pelhřimov WWTP
Na rozdíl od dř́vějšího modelu hospodaření, kdy převážnou většinu plodin tvořily obiloviny a brambory pěstované v několikaletém osevním postupu, se nyní přechází na velkoplošné pěstování technických plodin, zejména řepky a kukuřice. Tyto plodiny však současná zemědělská praxe "neumí pěstovat bez použití pesticidních látek (prostředků na ochranu rostlin) [1]. Podle údajů z webových stránek ÚKZUZ byla v okrese Pelhřimov v r. 2014 evidována spotřeba více než 78 t prostředků na ochranu rostlin, v okrese Benešov bylo spotřebováno více než 91 t. Celorepubliková spotřeba pak činila 5 tis. t v roce 2014 (obr. 7). Z porovnání informací o spotřebě pesticidních látek (www.ukzuz.cz) je zřejmé, že za posledních 15 let celková spotřeba prostředků na ochranu rostlin v České republice mírně klesla. Mění se však spektrum používaných látek a pravděpodobně i jejich účinnost a mechanismus účinku. Spotřeba látek na ochranu kukuřice a řepky v průběhu let kolísá a pohybuje se za Českou republiku přibližně v okolí hodnot 500-700 tun pro kukuřici a 1200-1900 tun pro řepku.

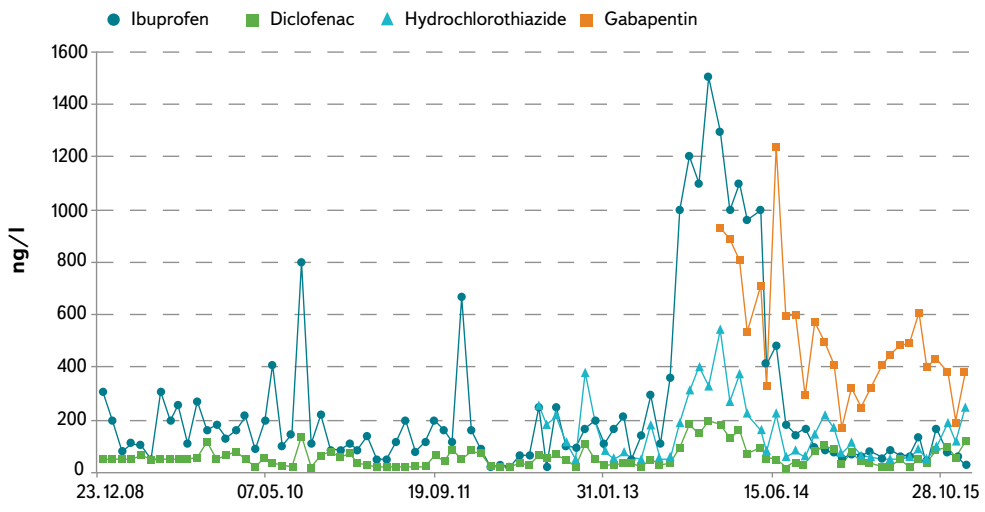

Obr. 4. Vývoj koncentrací vybraných léčiv v toku Bělá (pod vypouštěním OV z II. biologického rybníka ČOV Pelhřimov)

Fig. 4. Long-term trend of concentration of selected drugs in the Bělá River (outlet of second biological pond of Pelhřimov WWTP)

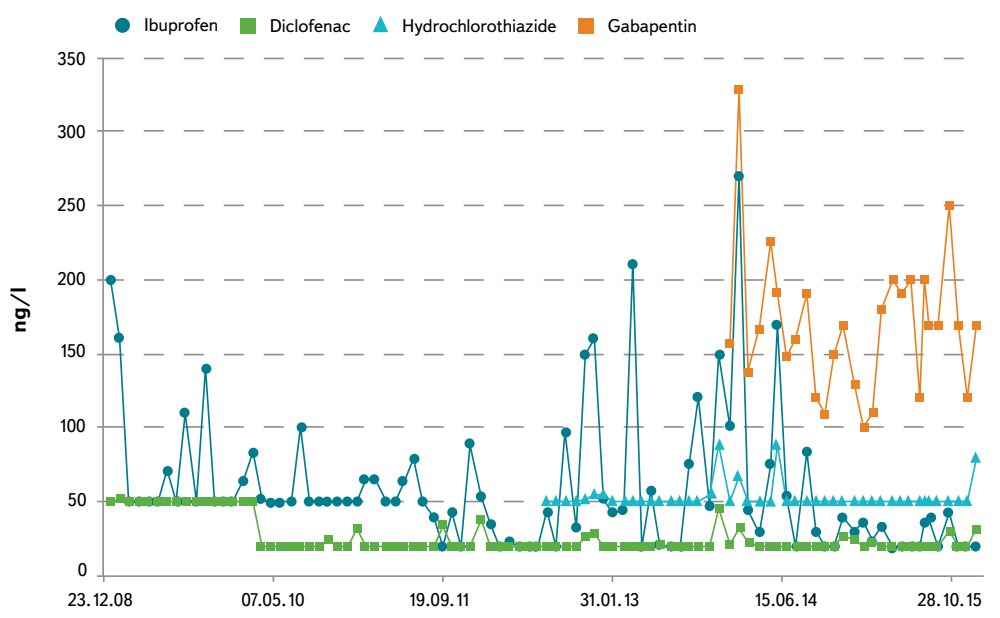

Obr. 5. Vývoj koncentrací vybraných léčiv na hlavním př́toku nádrže VN Švihov Fig. 5. Long-term trend of concentration of selected drugs in the main tributary of Švihov water reservoir 


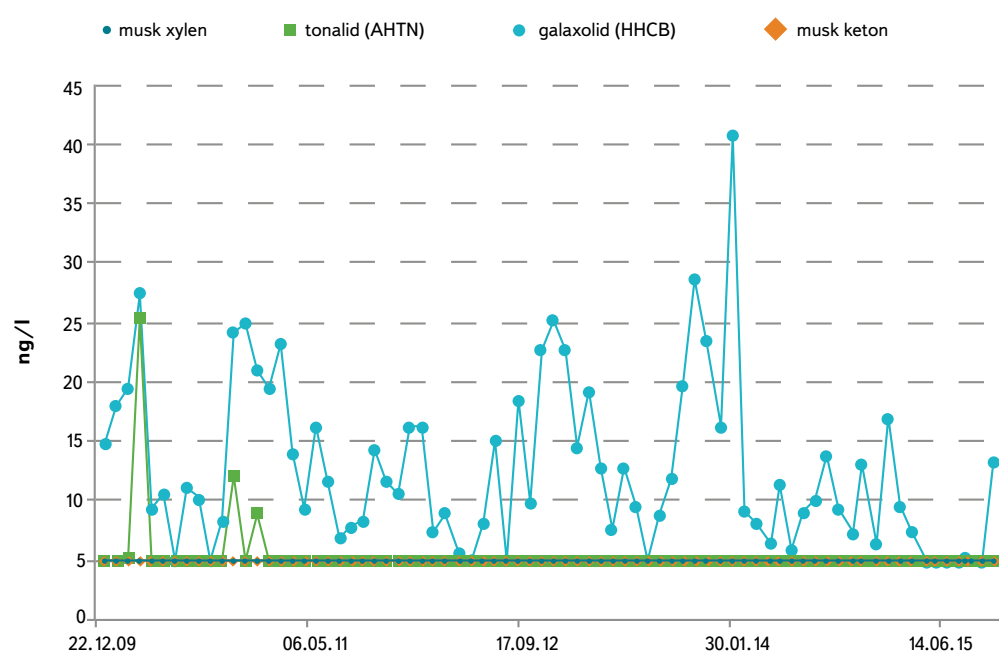

Obr. 6. Vývoj koncentrací mošusových látek na hlavním př́toku nádrže VN Švihov

Fig. 6. Long-term trend of concentration of musk compounds in the main tributary of Švihov water reservoir

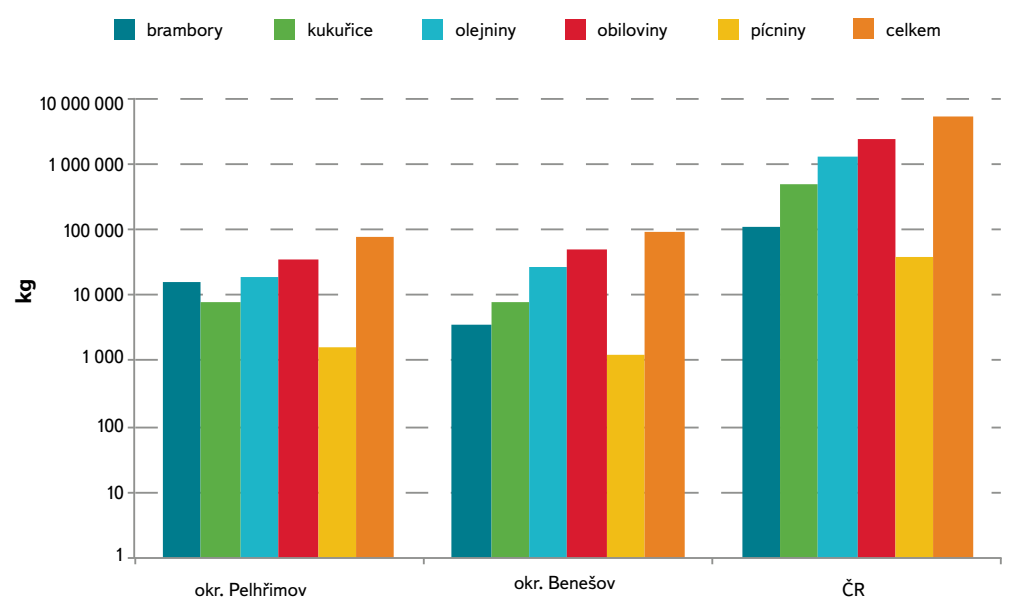

Obr. 7. Ilustrace spotřeby pesticidních látek v roce 2014 v okrese Benešov a Pelhřimov (zdroj: ÚKZUZ)

Fig. 7. Overview of the pesticides comsumption in Benešov and Pelhřimov districts in 2014 (source: ÚKZUZ)

Plošné znečištění vod je způsobeno vyplavováním látek z půdního profilu nebo odtokem povrchové vody po povrchu terénu. Důsledkem toku povrchové vody po povrchu půdy za extrémních srážko-odtokových situací či určitých zemědělských podmínek (dlouhé svahy, management půdy) je eroze půdy, prričemž spolu s půdními částicemi odchází do vodních toků i látky na tyto částice navázané (např. fosfor) nebo ve vodě rozpuštěné, tj. pesticidní látky a jejich metabolity. Odtok vody po povrchu je v radě prípadů nahodilý v čase i místě povodí, rovněž průnik látek půdním profilem je velmi specifický. Půdy jsou většinou plošně, ale i vertikálně heterogenní (často značně propustné), a to jak z hlediska infiltrace vody do půdy, tak i z hlediska průtoku vody půdním profilem. Management využívání půd se v jednotlivých povodích IV. rádu liší. Spolu s rozdílnými meteorologickými a variabilními prírodními podmínkami v jednotlivých letech je identifikace a predikce plošného znečištění velmi obtí̌̌ná [1, 9].

Z monitoringu výskytu pesticidů v povodí vodárenské nádrže Švihov bylo zjištěno, že za nejvíce kontaminované toky Ize označit řeku Trnavu, Martinický potok a Sedlický potok, který ústí nedaleko hráze nádrže [1]. Obrázek 8 znázorňuje vývoj koncentrace terbutylazinu, který se používá k likvidaci plevelů v kukuřici, v toku, který odvodňuje zemědělsky intenzivně obhospodařované povodí Sedlického potoka $v$ různě vodných letech. Je zde patrná výrazná spojitost s hydrologickou situací v daném roce. Z poklesu koncentrace v roce 2012 a významného pak v roce 2013, 2014 a 2015 Ize usuzovat bud' na změnu osevních postupů (náhrada kukuřice za jinou plodinu), což s sebou přináší např. snížení aplikační dávky terbutylazinu, nebo byl tento pesticid zčásti nahrazen jinou látkou (ústně potvrzená informace od místně hospodařících zemědělských subjektů). Skutečností je, že v roce 2012 bylo používání terbutylazinu v ochranných pásmech vodních zdrojů legislativně omezeno.

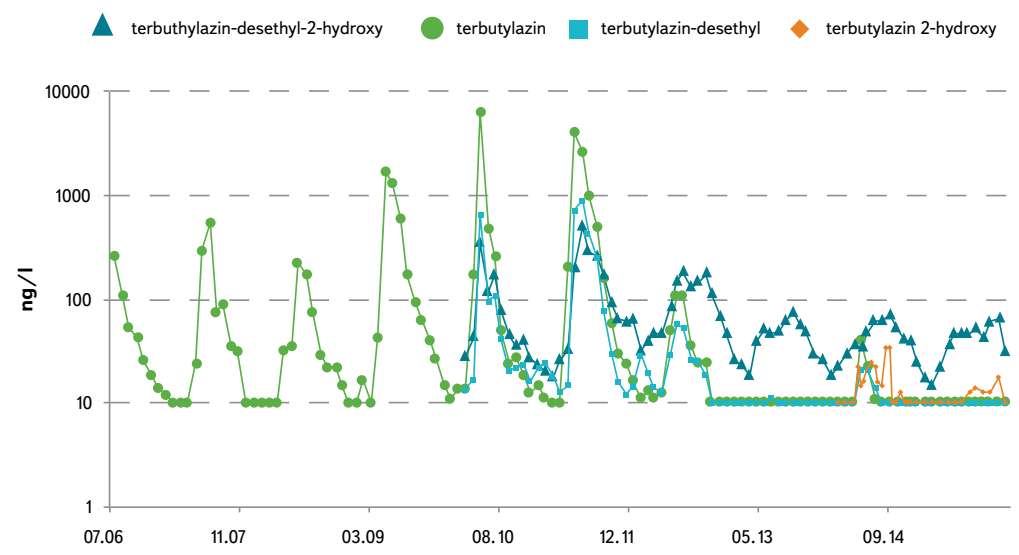

Obr. 8. Dlouhodobý vývoj koncentrace terbutylazinu a jeho metabolitů v Sedlickém potoce Fig. 8. Long-term trend of concentration of terbutylazin and its metabolites in Sedlický brook

Výslednou koncentraci pesticidů a jejich metabolizovaných forem ve vodách ovlivňuje množství faktorů, mezi které patří především velikost aplikované dávky, období a způsob aplikace. Významnou roli hraje i charakter povodí (zejména svažitost terénu, půdní a (hydro)geologické podmínky či př́tomnost a funkčnost zemědělského odvodnění), dále také hydrologická situace $v$ daném roce. $\checkmark$ zemědělské praxi se pesticidy aplikují obvykle $v$ jarním a podzimním období. Následný výskyt těchto látek $v$ povrchových vodách pak závisí na srážko-odtokové situaci. Pokud jsou pesticidy aplikovány v období častých nebo intenzivních srážek, dochází k jejich smyvu povrchovým odtokem, rychlému vymývání z půdního profilu či transportu preferenčním prouděním. Povrchovým nebo podpovrchovým odtokem pronikají pesticidy do vodních toků, kde se vyskytují ve vyšších koncentracích, ale po kratší časové období. Výrazně nižší koncentrace pesticidů bývají naopak zaznamenány v suchých letech, dokladem toho byl i suchý rok 2015. Z pohledu transportu pesticidů z polí jsou meliorační odvodňovací řady bodovým zdrojem pesticidních látek pro povrchové vody.

Při studiu kinetiky pesticidů byl v povrchových vodách povodí VN Švihov pozorován i vliv období aplikace látek, kdy se nejvy̌̌ší koncentrace rodičovských pesticidních látek vyskytují ve srážkově průměrných letech, v období jejich aplikace, tj. pozdní jaro a počátek léta, u některých látek také ještě v podzimních měsících. Na jaře jsou zpravidla zaznamenávány vyšší koncentrace rodičovských látek terbutylazinu, acetochloru, metazachloru, metolachloru a některých uronových pesticidů, např. linuronu. Na obr. 9 jsou zobrazeny nejvyšší naměřené koncentrace terbutylazinu v období 2009-2015. Nálezy rodičovských pesticidních látek ve vodách jsou závislé na časové "souhře" data odběru vzorků, aplikace látek na pole a srážkového režimu. V suchých letech (např. 2015) byly koncentrace rodičovských látek v povrchových vodách velmi nízké, protože z půdního profilu byly vyplavovány minimálně nebo vůbec. Na obr. 10 jsou zobrazeny nejvyšší naměřené koncentrace metabolitu chloracetanilidových pesticidů - metazachloru ESA, v období 2009-2015. 
U forem kyselých derivátů pesticidů (formy ESA a OA u chloracetanilidů) je roční vývoj jejich koncentrací v tocích více vyrovnaný a nezávisí v takové míre na velikosti aplikované dávky $v$ sezoně jako u rodičovských látek. Určité závislosti na srážkovém režimu a období aplikace jsou zřejmé, avšak podstatné je, zda jsou odvodňované zemědělské plochy zorněné nebo zatravněné a zda jsou aktuálně zemědělsky využívané, či nikoli [9].

Z pohledu ovlivnění kvality vody v samotné VN Švihov má vzhledem k celkovému objemu vody velký význam hlavní přítok vody do nádrže (profil Želivka-Pořičí). V období vegetační sezony přichází do nádrže velký objem vody s obsahem pesticidních látek, v zimním období se pesticidy obohacená voda $v$ nádrži spíše ředí (obr. 11), týká se zejména rodičovských látek. Z obr. 12 je zřejmé, že koncentrace některých metabolitů pesticidních látek není prímo závislá na vegetační sezoně, roční průběh je vyrovnanější. Oproti tomu na obr. 13 jsou pro metazachlor ESA patrné maximální hodnoty právě ve vegetační sezoně [1].

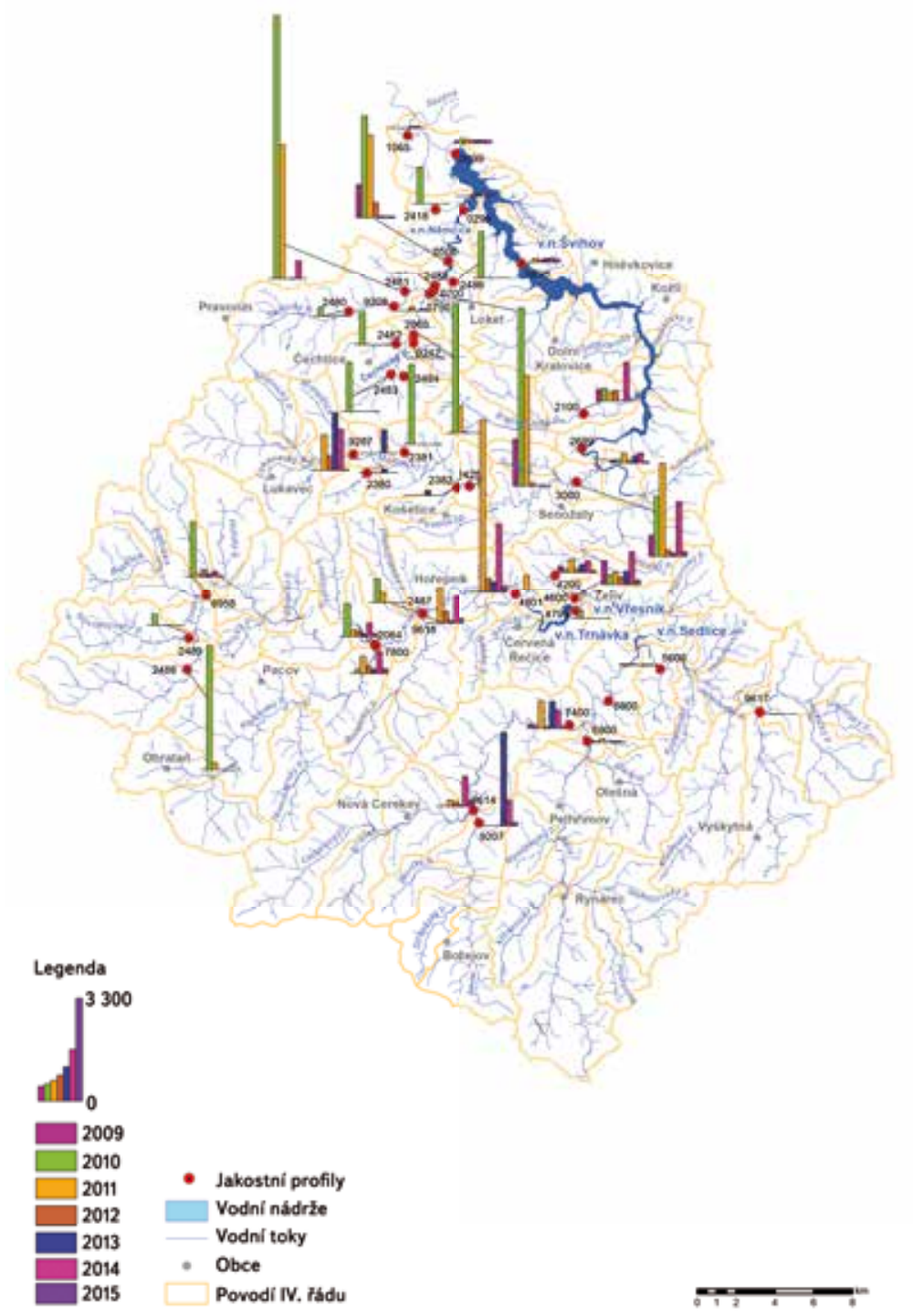

Obr. 9. Maximální koncentrace terbutylazinu (ng/I) naměřené v povrchových vodách v povodí VN Švihov v období 2009-2015

Fig. 9. Maximum concentration of terbutylazin measured in surface water across the river basin of the Švihov water reservoir
Z hlediska vývoje koncentrací pesticidních látek v horizontálním profilu má vodní nádrž Švihov v systému „nádrž - povodí" tlumicí a vyrovnávací funkci. $\checkmark$ nádrži ( $v$ prostoru před hrází) jsou nalézány koncentrace pesticidních látek, (např. terbutylazinu, v rozpětí cca 30-150 ng/l) o několik rádů nižší oproti maximálním hodnotám dosahovaným na prítocích, a neoscilují tak výrazně jako na počátku vzdutí nádrže a v př́tocích (obr. 14). Tato skutečnost je "výhodou“ zejména z hlediska technologie úpravy vody, jelikož je odebírána surová voda s relativně vyrovnanou kvalitou a úpravna vody tak nemusí neustále reagovat na změny v kvalitě vstupní vody. Obrázek 15 ilustruje vývoj koncentrace vybraných metabolitů chloracetanilidových pesticidů u hráze nádrže, sezonní vývoj nevykazuje zásadní fluktuace.

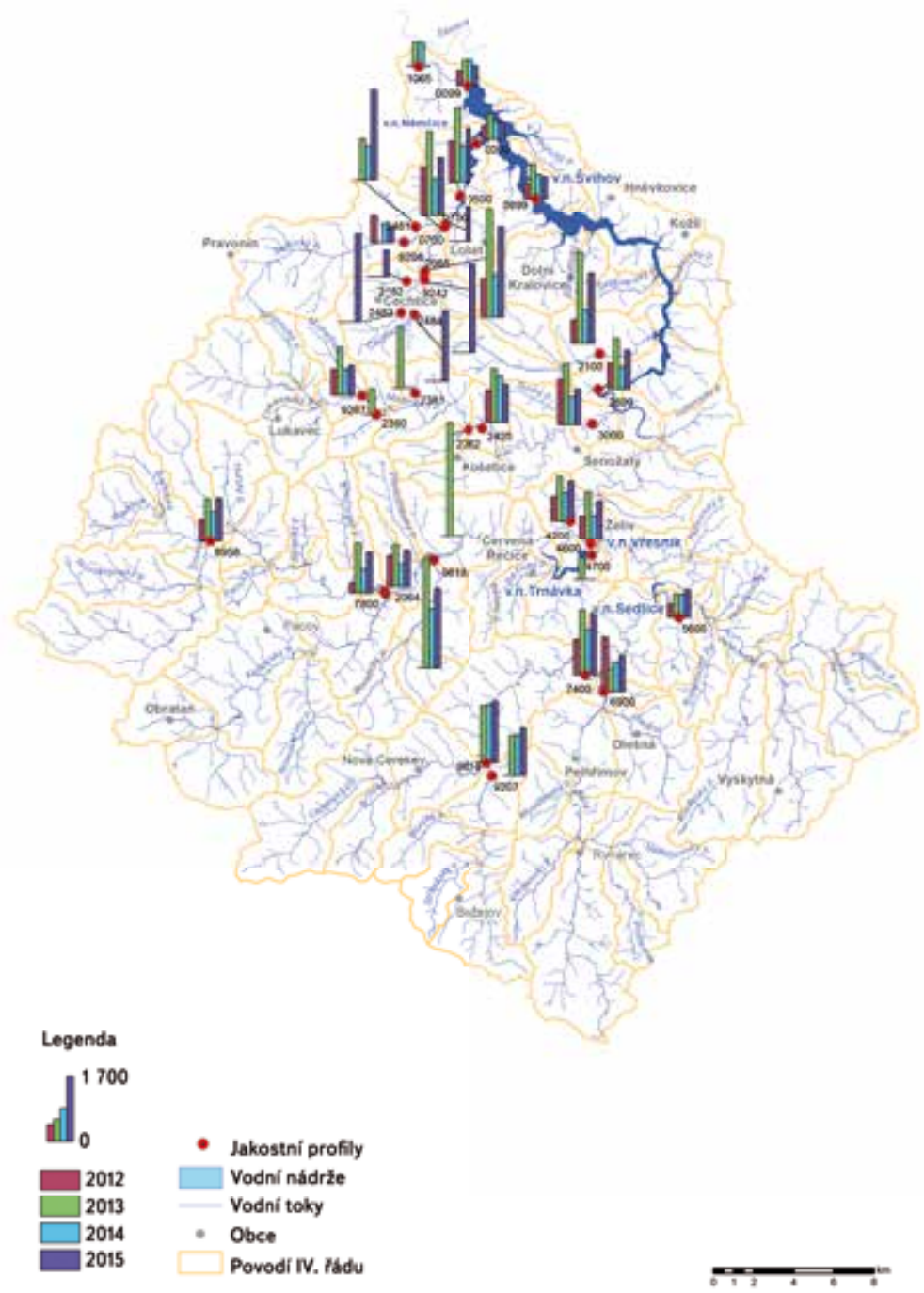

Obr. 10. Maximální koncentrace metazachloru ESA (ng/l) naměřené v povrchových vodách v povodí VN Švihov v období 2009-2015 Fig. 10. Maximum concentration of metazachlor ESA measured in surface water across the river basin of the Švihov water reservoir 


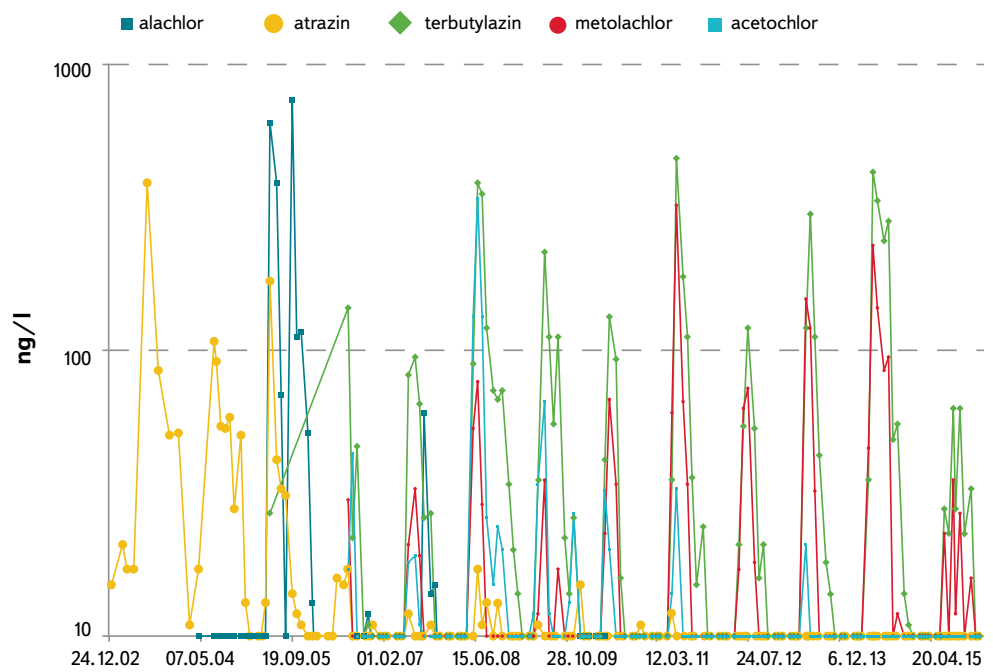

Obr. 11. Vývoj koncentrace pesticidů v hlavním př́toku do VN Švihov (rodičovské látky) Fig. 11. Long-term trend of concentration of pesticides in the main tributary of Švihov water reservoir (prime compounds)

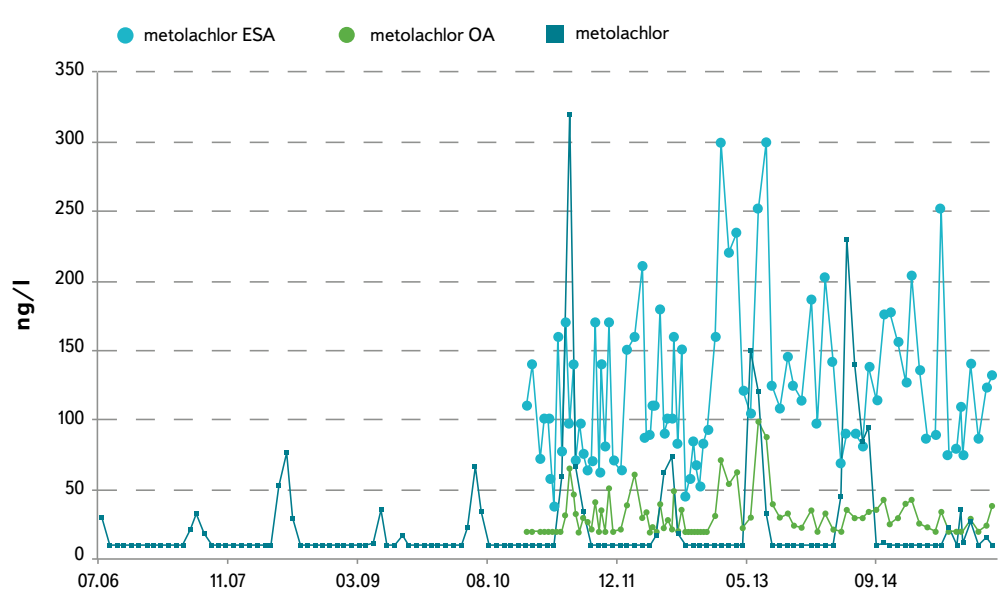

Obr. 12. Vývoj koncentrace metolachloru a jeho metabolitů v hlavním prítoku do VN Švihov Fig. 12. Long-term trend of concentration of metolachlor and its metabolites in the main tributary of Švihov water reservoir

\section{metazachlor metazachlor OA metazachlor ESA}

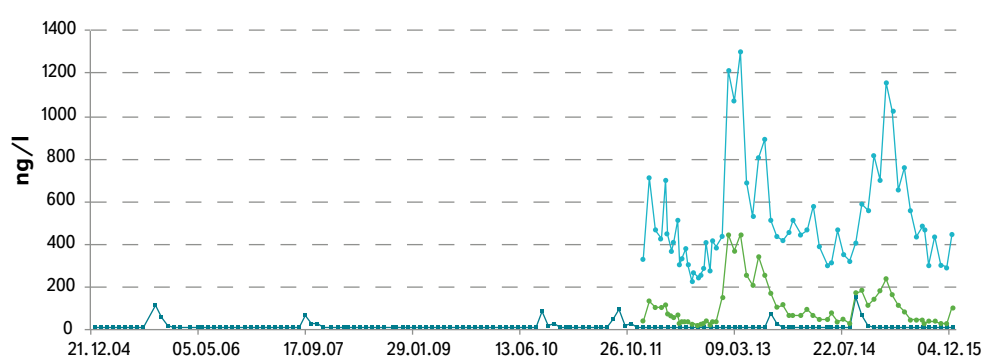

Obr. 13. Vývoj koncentrace metazachloru a jeho metabolitů v hlavním př́toku do VN Švihov Fig. 13. Long-term trend of concentration of metazachlor and its metabolites in the main tributary of Švihov water reservoir

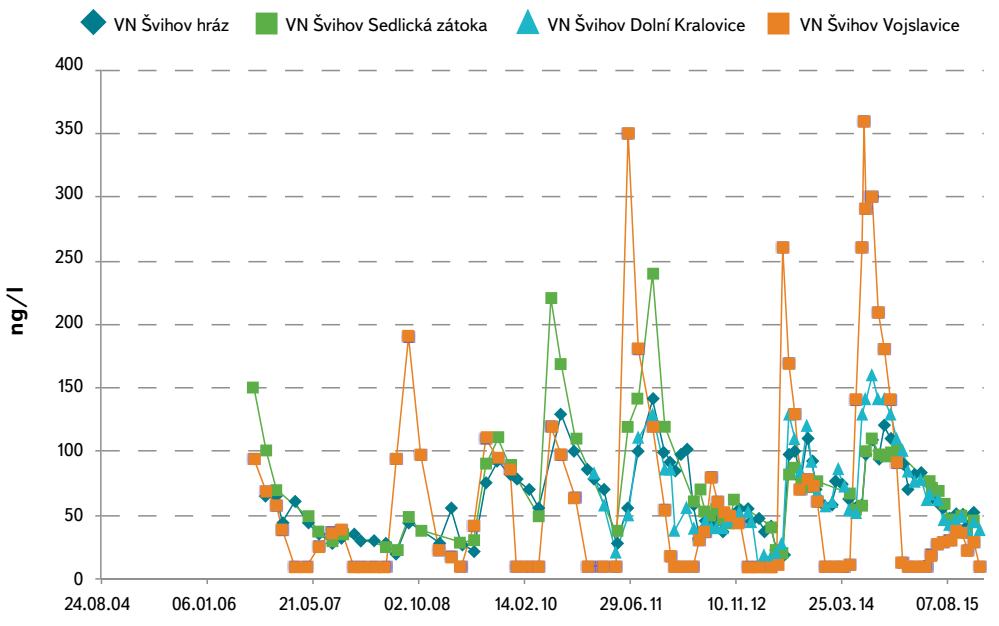

Obr. 14. Vývoj koncentrace terbuthylazinu v nádrži VN Švihov

Fig. 14. Long-term trend of concentration of terbutylazin in the Švihov water reservoir

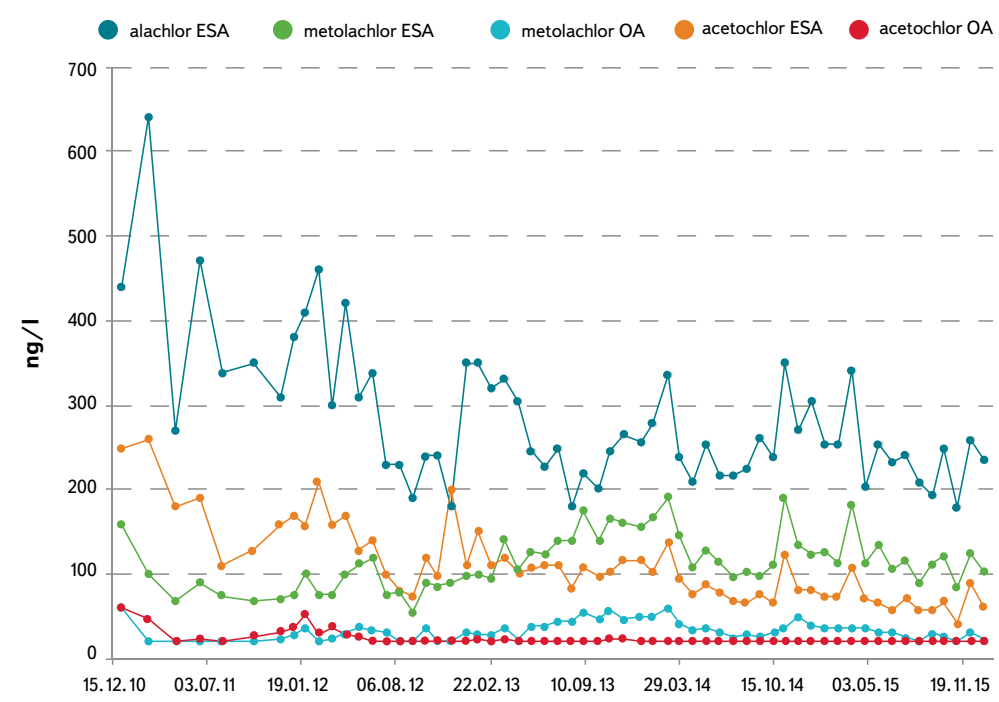

Obr. 15. Vývoj koncentrace vybraných metabolitů chloracetanilidových pesticidů u hráze nádrže

Fig. 15. Long-term trend of concentration of selected chlorine-acetanilide metabolites in the Švihov water reservoir dam 


\section{ZÁVĚR}

Povodí VN Švihov je poměrně výrazně atropogenně ovlivněno, a to zejména prítomností a aktivitou zde žijících obyvatel a intenzivní zemědělskou činností, což má výrazný vliv na jakost vody v povodí VN Švihov a v nádrži samotné. Jakost vody je ovlivněna vyššími koncentracemi živin, zejména fosforu [2], který je prričinou vysoké eutrofizace toků, dále pesticidními látkami, které jsou používány $v$ zemědělské produkci technických (kukuřice, řepka) a potravinářských (obilniny, brambory atd.) plodin [1]. Způsob zemědělského obhospodařování je prríčinou rozsáhlé eroze zemědělské půdy a její sedimentace $v$ tocích a nádržích. Poměrně husté lidské osídlení povodí VN Švihov má i další důsledky, nebot’ s živinami v odpadních vodách se do toků dostávají i další cizorodé látky, jako např. léčiva, hormonální přípravky, kosmetické prípravky, antikoroziva, změkčovače plastů - bisfenol A a řada dalších látek lidské denní potřeby [8]. Všechny tyto specifické a prírodně nepůvodní látky vytvářejí směs (tzv. koktejl), jejíž vliv na životní prostředí nelze odhadnout, přičemž vzájemné působení látek může mít výrazný zatím bliže nedefinovaný synergický účinek [7]. Stejně jako pesticidní látky, tak i např. léčiva se mění na jednotlivé metabolické produkty, které zatím nejsou pomocí současné laboratorní techniky identifikovány, avšak Ize predpokládat, že ve vodě v rưzných formách přetrvávají. Z porovnání aplikovaných množství pesticidních látek a měřených koncentrací v povrchových vodách Ize usuzovat, že pomocí současné analytické instrumentace je stanoven pouze zlomek skutečně prítomného množství těchto látek ve vodě [7]. Pesticidní a další látky se pravděpodobně ve vodě vyskytují v dalších formách, které současná analytická technika zatím nerozpozná. Proto je důležité se této problematice věnovat a pracovat na dalším rozvoji analytických metod ve smyslu identifikace nových látek, což však pro analytické laboratoře představuje značné finanční náklady.

$\checkmark$ důsledku intenzivní zemědělské výroby, která je významně ovlivňována dotační politikou ČR i EU, nelze jednoznačně predikovat vývoj plošného zemědělského zatížení povrchových i podzemních vod pritékajících do nádrže. Není však predpoklad výrazné změny současného stavu a současně nelze dlouhodobě predikovat ani vývoj dotační politiky EU. Rizikem je a vždy bude již započatá změna tradičních zemědělských osevních postupů a technologií a podpora plošného rozširíení technologicky využitelných plodin, např. pro výrobu biopaliv nebo jako energetický substrát pro bioplynové stanice, popř. dalších technologií nepríznivých k ochraně vody.

V rámci stanovení ochranných pásem VN Švihov na Želivce jsou pro hospodařící zemědělské organizace určena opatření k minimalizaci negativních vlivů na jakost vody v nádrži. Jedná se především o snižení vnosu reziduí pesticidních látek do povrchových vod ve vodárenském povodí a související protierozní opatření. Navržená opatření spočívají v aplikaci pozemkových úprav, ve změně způsobu hospodaření a dále $v$ budoucí přeměně vybraných pozemků z orné půdy na trvalý travní porost. Časový horizont zatravnění některých oblastí je však v průběhu 5 až 10 let, což dále predikuje přetrvávající riziko znečištění povrchových vod pesticidními látkami.

\section{Literatura}

[1] LIŠKA, M. a kol. Problematika výskytu pesticidních látek v povrchových vodách v povodí vybraných vodárenských zdrojů. Vodní hospodářství, 2015, 1, s. 14

[2] DOBIÁŠ, J., DURAS, J. a FOREJT, K. Změna vstupu fosforu do vodárenské nádrže Švihov a jejího povodí v období rekonstrukce ČOV Pelhřimov. Sborník konference Vodní nádrže, 2015, 6.-7. řijna 2015, Brno, Kosour D. (Edit.), s. 101

[3] DURAS, J. Jak se sucho 2015 projevilo v kvalitě stojatých vod. Sborník konference Vodárenská biologie, 2016, 3.-4. 2. 2016, Praha, Říhová Ambrožová Jana (Edit.), s. 77.

[4] DURAS, J., MARCEL, M., ŠEBESTA, V. a NOVOTNÁ, V. Rekonstrukce ČOV Pelhřimov - řešení situace na pretížených biologických rybnících a vliv na recipient. Vodní hospodárství, 2015, 4, s. 1.
[5] FOLLER, J. Snižování odtokových koncentrací fosforu v boji proti eutrofizaci toků je i u malých ČOV akceptovatelným, snadno a jednoduše řešitelným požadavkem. Vodní nádrže, 2012, 26.-27. záři 2012, Brno, Česká republika, Kosour D. (Edit.), s. 63.

[6] LIŠKA, M., SOUKUPOVÁ, K., KULE, L., METELKOVÁ, A. a KOŽELUH, M. Výskyt farmak v povrchových a odpadních vodách povodí Vltavy "ve světle" konference Water and Health - Ženeva/Annemasse 2015. Vodníhospodárství, 2015, 11, s. 1.

[7] KOŽí̌̌EK, F. Pitná voda a relevantní metabolity pesticidů: současný stav řešení problému v České republice. Rostlinolékař, 2015, 5, s. 27.

[8] LIŠKA, M., SOUKUPOVÁ, K., KULE, L., METELKOVÁ, A. a KOŽELUH, M. Farmaka našich vod. Vodni nádrže, 2015, 6.-7. ŕíjna 2015, Brno, Česká republika, Kosour D. (Edit.), s. 125.

[9] STALLMAN, R.S. and JAMES, H.S. Determinants affecting farmers willingness to cooperate to control pests. Ecological Economics, 2015, 117, s. 182

\section{Autoři}

RNDr. Marek Liška, Ph.D.

凶marek.liska@pvl.cz

\section{Ing. Kateřina Soukupová}

凶katerina.soukupova@pvl.cz

\section{Mgr. Jakub Dobiáš}

凶jakub.dobias@pvl.cz

\section{Ing. Antonia Metelková}

$凶$ antonia.metelkova@pvl.cz

\section{Ing. Jan Goldbach}

凶jan.goldbach@pvl.cz

Ing. Tomáš Kvítek, CSc.

凶tomas.kvitek@pvl.cz

Povodí Vltavy, s. p.

Příspěvek prošel lektorským řízením. 


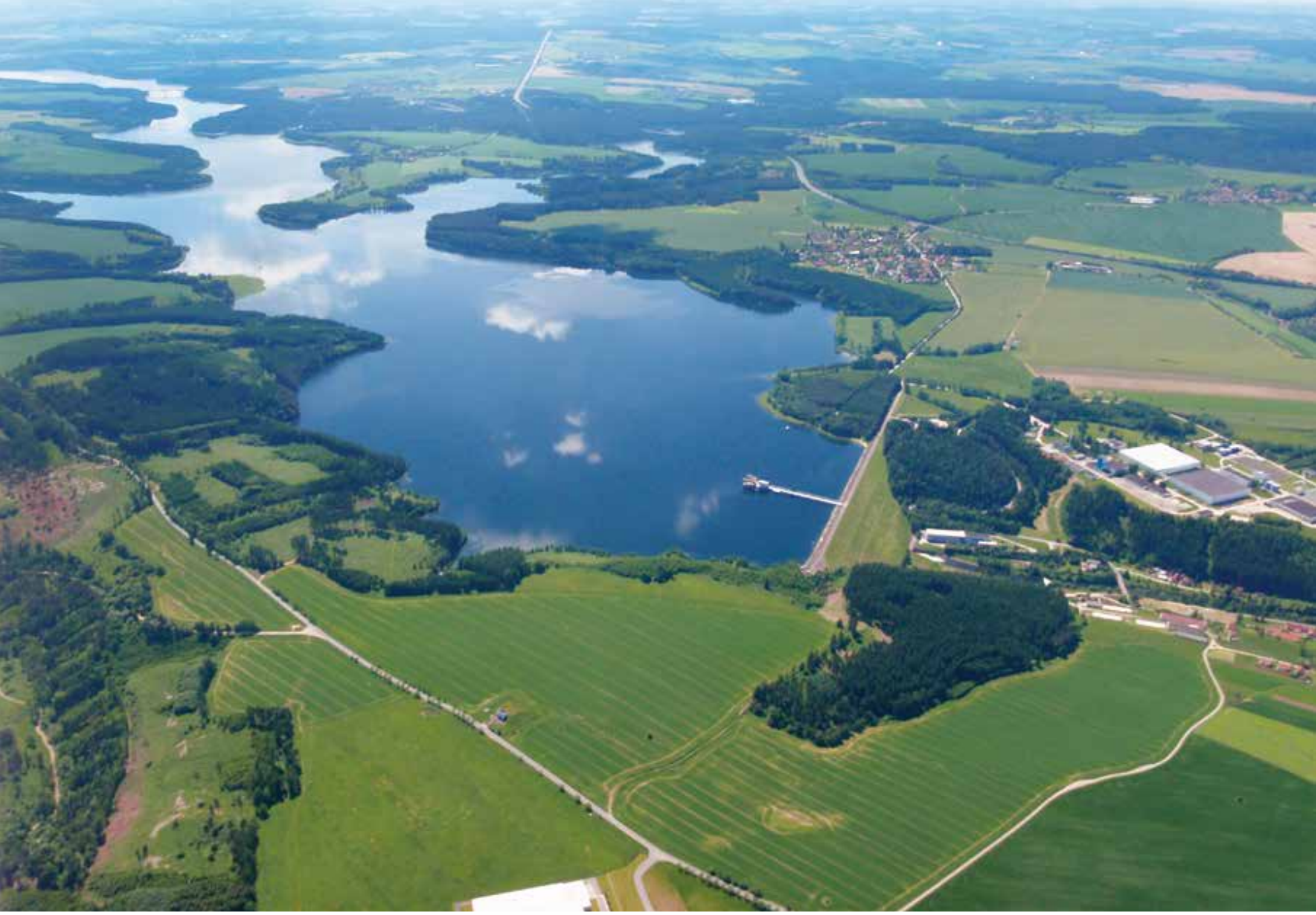

\section{WATER QUALITY IN DRINKING WATER RESERVOIR ŠVIHOV ON ŽELIVKA RIVER AND ITS RIVER BASIN, WITH FOCUS ON SPECIFIC ORGANIC COMPOUNDS}

\section{LISKA, M.; SOUKUPOVA, K.; DOBIAS, J.; METELKOVA, A.; GOLDBACH, J.; KVITEK, T.}

Povodí Vltavy, State Enterprise

Keywords: Švihov water reservoir - phosphorus - pesticides drugs - point - nonpoint source of pollution

River basin of the largest drinking water reservoir Švihov on the Želivka River is distinctly anthropogenically affected both by direct human activities and also by the agriculture. The quality of the surface water is endangered in longterm period mainly by the eutrophication, pesticides pollution and erosion.
Higher concentrations of phosphorus originally from point sources cause higher degree of the river eutrophication. The way of agricultural management supports extensive farmland erosion and subsequently sedimentation of that material in the rivers and reservoirs. Increased concentrations of pesticides compounds coming mainly from agricultural production are found in drainage and surface water in the Švihov water reservoir catchment area. Not only nutrients but also other specific pollution compounds from wastewater are found in the rivers eg. drugs, hormonal substances, personal care products, anticorrosive substances, BPA and others. Pesticides and drugs turn in their individual metabolic products, which persist in various forms in the water. From the long term, the transition to the cultivation of industrial crops is very risky with serious consequences for water quality, especially in the river basin of water reservoirs. 